\title{
Må vi trene for å ha god helse?
}

\author{
De siste årene har vi vært vitne til en formidabel medieoppmerksomhet omkring trening, \\ kropp og fysisk aktivitet. Statlige instanser, medier, instruktører og helsepersonell formidler \\ et entydig budskap: For å holde oss friske må vi trene mer. Det finnes i dag overbevisende \\ dokumentasjon på at lite kroppslig aktivitet over tid utgjør en betydelig sykdomsrisiko. \\ Men hva slags kroppslig aktivitet er helsefremmende?
}

\section{Åse Bårdsen}

ase.bardsen@uit.no

Institutt for helse og omsorgsfag

Det helsevitenskapelige fakultet

Universitetet i Tromsø

9037 Tromsø

\section{Eline Thornquist}

Institutt for fysioterapi

Høgskolen i Bergen

Treningsbegrepet er nå så innarbeidet at vi knapt tenker over hva som ligger i det. En vanlig definisjon på trening er «fysisk aktivitet som er planlagt, strukturert og gjentas, og som har som mål å bedre eller vedlikeholde fysisk form» (1). Her dreier det seg om klare mål - sterk(ere), rask(ere), (mer) utholdende - og for å få effekt kreves høy intensitet. Helsefremmende aktivitet, derimot, inkluderer alt som involverer kroppslig deltakelse - gå på tur, leke, danse, sykle til skole og arbeid m.m. Det har lenge vært kjent at det ikke er nødvendig å trene (planmessig, strukturert og med høy intensitet) for å oppnå helsemessig gunstig effekt $(1,2)$. På denne bakgrunn er det viktig å rette oppmerksomheten mot begrepet «helserelatert form». Det knyttes primært til biokjemiske og hormonelle forhold der man er opptatt av virkninger på immunforsvar, blodsirkulasjon og omsetning av næringsstoffer som fett og karbohydrater. For å oppnå slike virkninger er regelmessig, moderat kroppslig aktivitet tilstrekkelig for de fleste $(1,2)$.

Svaret på spørsmålet i overskriften er altså nei. Å gå i moderat tempo, gjerne slik at man blir andpusten eller varm i til sammen 30 minutter daglig, er nok for de fleste. På tross av dette fremstår trening som saken. Aviser, magasiner og tidsskrifter fylles opp av utdrag fra forskningsrapporter og kartlegginger, og vi kan knapt åpne en avis uten å støte på mer eller mindre velfunderte treningsopplegg og anbefalinger.

Helsedirektoratet ga i 2009 ut Aktivitets- håndboken (2). Hensikten var å samle den forskningsbaserte kunnskapen om fysisk aktivitet og trening mellom to permer. Slik skulle boken være til hjelp i det daglige arbeidet med å få pasienter og befolkningen for øvrig til å øke sin fysiske aktivitet. Den leverer generelle og samtidig detaljerte opplysninger om trening, i stor grad sortert ut fra diagnoser. Men det gir lite mening å forutsette at mennesker med samme diagnose eller problem, det være seg depresjon, diabetes eller høyt blodtrykk, har nytte av eller lyst til å drive med samme type aktivitet. Det tales også med to tunger: På den ene side understrekes det at moderat aktivitet er viktig og helsefremmende, på den annen side dominerer kapitlene der forfatterne er svært opptatt av spesifikke treningsråd basert på en tenkning om tradisjonelle treningseffekter som utholdenhet og styrke.

Hovedproblemet i dag er at hverdagsaktivitetene er i ferd med å forsvinne og at det bygges opp under en oppfatning om at vi sikrer oss god helse dersom vi følger tradisjonelt anerkjente treningsprinsipper. Samtidig som flere og flere trener regelmessig, viser ferske tall at kun $20 \%$ av den voksne befolkningen beveger seg nok i forhold til anbefalingene (3). Det blir altså stadig mindre av den type hverdagslig kroppslig aktivitet som de fleste ikke oppfatter som trening.

Etter mange års klinisk arbeid med både voksne og barn er vår erfaring at folk flest liker å være i bevegelse. Samtidig har en del av dem som kommer inn under kategorien «fysisk inaktive» dårlige erfaringer med trening og bevegelse. Minner fra gymtimer, idrettsdager og friminutter fremkaller ubehag og skaper negative assosiasjoner. Det er veldokumentert at vi husker bedre og preges dypere av det som er følelsesmessig farget - både i positiv og negativ forstand $(4,5)$. Den enkeltes tidligere erfaringer med fysisk aktivitet og trening vilvære av avgjørende betydning $i$ et endringsarbeid.

Et viktig spørsmål blir derfor hva som kan øke lysten og skape et bedre forhold til bevegelse. Når vi argumenterer for bevisstgjøring av forskjellen på «helsefremmende aktivitet» og «trening», er det fordi valg av ord og begrep har betydning. «Trening» er et greit begrep for dem som allerede liker å trene. Men dagens hovedutfordring gjelder dem som aldri har trent og som ofte forbinder trening med ork og ubehag. Overfor dem kan det være avgjørende å bruke et språk som fremmer lyst og motivasjon. Men selv om ord er viktig, er positiv egenerfaring og tro på egen mestringsevne det aller viktigste. Som kommunikasjonsstrategi er dagens vektlegging av trening neppe veien å gå. Problemene knyttet til redusert aktivitet, stillesitting og lite varierte bevegelser handler om mer enn å få befolkningen til å trene og følge bestemte treningsprinsipper. Gjennom å bruke begrepet «helserelatert form» ønsker vi å sette søkelyset på kroppens sammensatte funksjoner $\mathrm{og}$ på personers selvoppfatning og tro på egne krefter.

Mennesket er et sammensatt vesen vi er både en biologisk organisme og et erfarende og meningsskapende subjekt. Det handler altså ikke bare om dosering av fysisk aktivitet, men også om hvordan og med hvilken innstilling og opplevelse vi beveger oss.

\section{Egenverdi og selvforglemmelse}

I en tid med kropps- og helsefiksering er det viktig å holde fast ved at en aktivitet har en egenverdi. Å gå kan tjene som eksempel på hva som ligger i dette. Hvis du går for turens egen skyld, kan du la tankene vandre, kjenne på været og nyte omgivelsene. Inntrykk kan bearbeides, uro kanaliseres og gleden over rytme og flyt i bevegelsene kan gi stor tilfredsstillelse og frihetsfølelse. Du kan rette oppmerksomheten mot det du ser, hører og kjenner, du kan bestemme deg for å stoppe eller ta en annen vei.

Å gå for å trene krever noe annet. Bedret kondisjon forutsetter oppmerksomhet omkring hyppighet, varighet og intensitet og kanskje staver og skritteller. Det å gå blir da et middel, det blir ikke lenger et mål som 
knyttes til selve aktiviteten. Og en aktivitet må gi glede og mening, ellers gir man fort opp.

En aktivitet kan med andre ord være et mål i seg selv - eller et middel til å oppnå noe utenfor selve aktiviteten (6). Mål og middel må da forstås som ytterpunkter på et kontinuum, med mange muligheter for både-og-tilfeller. Barns lek brukes ofte som eksempel på en aktivitet som er et mål i seg selv. Hoveddelen av idretts- og treningsaktiviteter er middelstyrt eller instrumentelt styrt, i og med at målet er å finne utenfor selve aktiviteten. Målet kan være å vinne en konkurranse, bli mer utholdende, bli slankere eller fastere i fisken. Er motivasjonen sterk nok, kan opplevelsen av selve aktiviteten bli underordnet.

I dag dreier mye trening seg om prestasjon og selvpresentasjon. Trening kan oppleves som tvang og plikt, ofte styrt av pulsklokker og kaloritelling, med uheldige og lite helsefremmende konsekvenser. I en uoversiktlig verden der alt går stadig fortere og ymse tilbud sammen med en økende informasjonsflom presser seg på, kan det være like viktig med ro og tilstedeværelse som trening og aktivitet. Og - ikke minst veksling mellom aktivitet og ro, arbeid og hvile er en gammel og god leveregel som helsepersonell med fordel kan trekke mer frem.

Vi vet at smerter og ulike belastningsplager er vanlig i alle aldersgrupper i Norge $i$ dag. Mange av dem som defineres som fysisk inaktive, oppgir at de unngår aktivitet pga. smerter, stivhet og andre funksjonsproblemer. I slike tilfeller vil aktiviteter som gir naturlig strekk, elastisitet og tøybarhet i muskulatur og bindevev kunne være til bedre hjelp enn trening for å stramme opp, bli hurtigere eller sterkere. Vår erfaring er at stivhet og anspenthet ofte lettes bedre gjennom rytmisk naturlig aktivitet enn gjennom øvelser i pust, avspenning og ulike former for kroppsbevissthet.

Et problem med dagens sterke vektlegging av trening er at det bidrar til selvsentrering - oppmerksomheten vendes mot kropp, utseende og prestasjon. Å gjøre kropp og helse til sentrum i tilværelsen bør ikke være målet for helsepersonell. Snarere er det viktig å stimulere til deltakelse og engasjement i det vi gjør, i verden omkring oss og i andre mennesker. De fleste av oss har det best når vi glemmer kropp og helse, når vi ikke tenker på egen og andres form og fasong, teller kalorier eller regulerer pusten, men er oppslukt og til stede her og nå i de ulike gjøremål.

Et underkjent perspektiv på bevegelse og fysisk aktivitet er den betydning somatosensorisk stimulering har for menneskers opplevelse av seg selv. Dette henger sammen med den økte impulsaktiviteten vi får fra reseptorer i ledd, sener og muskulatur når vi er i bevegelse. Disse proprioseptive signalene har to hovedfunksjoner. Den ene knytter seg til normal, ureflektert og koordinert bevegelse. Som eksempel på denne funksjonen kan nevnes at vi når vi går i en trapp i mørket, «vet» vi hvor vi har beina våre selv om vi ikke kan se. Denne fornemmelsen har med kroppsskjema å gjøre vi kjenner kroppens stilling i rommet og kroppsdelenes innbyrdes plassering. Men propriosepsjon er også sentralt $\mathrm{i}$ fornemmelse og opplevelse av ens egen kropp som avgrenset og skilt fra omverdenen. Det dreier seg her om en ureflektert selvfornemmelse eller selvoppfatning, som ikke må forveksles med bevisste tanker og forestillinger om kroppen - altså refleksiv tankevirksomhet basert på persepsjon av kroppen som objekt (4).

Helt fra fødselen erfarer vi mennesker verden gjennom kroppen og kroppen gjennom verden. Propriosepsjon omtales som «the modality of the self par exellence» (7). Et eksempel på dette er måten barns utforsking av verden bidrar til at de lærer å bli kjent med seg selv og verden samtidig. Når hverdagen for mange, både unge og gamle, innebærer lite variasjon i bevegelse og aktivitet, er det derfor all grunn til å tro at det er uheldig på flere måter enn det som knytter seg til fysisk form og somatisk sykdom. Fordi fysisk inaktivitet betyr redusert somatosensorisk impulsaktivitet, vil det føre til at de fysisk inaktive får færre proprioseptive impulser som hjelper frem en tydelig opplevelse av dem selv og omgivelsene $(4,8,9)$. Dette åpner andre perspektiver på dagens situasjon, på hva som er utfordringene og på hvilke begrunnelser helsepersonell anvender i møte med pasienter og befolkning for øvrig.

\section{Mening og motivasjon}

Helsepersonell som selv har et positivt forhold til bevegelse og aktivitet, kan lett komme til å stille seg uforstående til pasienters manglende motivasjon og lyst til å komme i gang med fysisk aktivitet. Undersøkelser viser at om lag halvparten av dem som starter med organisert trening, vil slutte i løpet av relativt kort tid. En viktig grunn til frafallet er for høy intensitet (1). Jogging fører f.eks. til mer frafall enn opplegg basert på gåturer. Særlig i startfasen er det viktig ikke å legge opp til en intensitet som skaper ulyst og ubehag hos den enkelte.

Det er likevel ikke bare høy intensitet som kan forklare frafall. Lavterskeltilbud ser ut til å fungere best. De er kjennetegnet av at de er tilpasset og valgt av den enkelte, og aktiviteten drives i nærmiljøet sammen med andre (3). Tilhørighet og fellesskap øker gleden og motivasjonen og er, sammen med tett oppfølging og støtte, sentrale faktorer for å redusere frafall.

For å få til varig endring av daglige vaner er det den enkeltes egen opplevelse og verdisett som er avgjørende. Det viser seg at ønskede helseeffekter eller slankere kropp ikke er nok for å vedlikeholde eller skape varig endring - aktiviteten må gi noe mer. Mange beskriver fokusert oppmerksomhet, selvforglemmelse og sterke sanseopplevelser som drivkraften. Noen søker leken som frigjører fra rutinene i hverdagen, andre får styrket livsmot gjennom å erfare at de mestrer.

I dag står vi i fare for å gjøre bevegelse og fysisk aktivitet til et tema for eksperter, jevnfør uttrykk som å «foreskrive fysisk aktivitet» (2). Vi må passe oss for å gjøre enkel, naturlig aktivitet til vanskelig «medisin». Når bevegelse ikke lenger inngår som en integrert del av arbeids- og hverdagslivet, vokser det opp kommersielle treningstilbud - samtidig som helsepersonell snakker oftere og høyere om «aktivitet» i vitenskapelige termer. Resultatet kan lett bli at vi fratar folk troen på at de kan bevege seg uten å følge ekspertråd eller skaffe seg personlig trener. Det enkle er ofte det beste, men overraskende vanskelig å få til.

Oppgitte interessekonflikter: Ingen

Litteratur

1. Fysisk aktivitet og helse. Anbefalinger. Rapport 2/2000. Oslo: Sosial og helsedirektoratet, 2000.

2. Aktivitetshåndboken - fysisk aktivitet i forebygging og behandling. Oslo: Helsedirektoratet, 2009

3. Ommundsen Y, Aadland A. Fysisk inaktive voksne Norge. Oslo: Helsedirektoratet, 2009.

4. Gallagher S, Zahavi D. The phenomenological mind. An introduction to philosophy and cognitive science. London: Routledge, 2008.

5. Brodal P. Sentralnervesystemet. Oslo: Universitetsforlaget, 2007.

6. Deci EL. Intrinsic motivation. New York, NY: Plenum, 1975.

7. Rochat P. The infant's world. Cambridge, MA Harvard University Press, 2001.

8. Thornquist E. Kroppssyn og faglige utfordringer dag. Fysioterapeuten Fagekstra 2001: 68: 9-15.

9. Cole JD. Pride and a daily marathon. Cambridge, MA: MIT Press, 1995.

Manuskriptet ble mottatt 9.3. 2010 og godkjent 14.5. 2010. Medisinsk redaktør Anne Kveim Lie. 